\title{
Development and Validation of an ICP-MS Method for Simultaneous Determination of Selected Metals in Electronic Cigarette Aerosol*
}

\author{
by \\ Shintaro Ohashi \\ Product Quality Research Center, Japan Tobacco Incorporated, 6-2, Umegaoka, Aoba-ku, Yokohama, Kanagawa, Japan
}

\section{SUMMARY}

Safety and quality standards for electronic cigarettes (e-cigarettes) have been introduced regionally. In 2016, the U.S. Food and Drug Administration (FDA) issued a rule to regulate e-cigarettes, requiring to report harmful and potentially harmful constituents (HPHCs). In the United Kingdom, the British Standards Institution (BSI) specified the metals to be monitored for e-cigarettes. In this study, a method was developed and validated for the simultaneous determination of 13 metals (Be, Al, Cr, Fe, Co, Ni, Cu, As, $\mathrm{Se}, \mathrm{Ag}, \mathrm{Cd}, \mathrm{Sn}$ and $\mathrm{Pb}$ ) in e-cigarette aerosol. Furthermore, matrix effects of major constituents in the aerosol were investigated using glycerol or 1,2-propylene glycol solutions. E-cigarette aerosol was generated by a rotary smoking machine according to CORESTA Recommended Method $\mathrm{N}^{\circ} 81$ and collected by an electrostatic precipitator coupled to an impinger containing nitric acid. The collected aerosol was dissolved in nitric acid and an aliquot of this solution was analyzed by inductively coupled plasma mass spectrometry (ICP-MS) equipped with a collision/reaction cell.

The linearity of the calibration curve was observed in the range of 0.2 to $100 \mathrm{ng} / \mathrm{mL}$ for each analyte; the correlation coefficients were 0.998 or larger, the mean recovery of each standard level ranged from 92.6 to $104.5 \%$ and the relative standard deviation amounted to max. 9.5\%. Accuracy, repeatability and specificity were validated by spiking three different amounts of analytes into e-cigarette aerosol; the mean recovery of each spiking level ranged from 88.7 to $110.3 \%$ with a relative standard deviation amounting to max. 9.2\% for all analytes. Background contamination from aerosol generation and collection system existed for some analytes, especially for $\mathrm{Al}, \mathrm{Fe}, \mathrm{Cu}$ and $\mathrm{Sn}$. The potential sources of contamination should be identified and controlled to reduce the impact of contamination on quantification. In addition, the actual values for samples should be reported with method blank statistics. Increase of the concentrations of glycerol and 1,2-propylene glycol in the prepared sample led to the overestimation of As and Se. The amount of polyols in the collected aerosol should be monitored and controlled for the accurate quantification of As and Se. [Beitr. Tabakforsch. Int. 28 (2018) 2-13]

\section{ZUSAMMENFASSUNG}

Regional wurden Sicherheits- und Qualitätsstandards für elektronische Zigaretten (E-Zigaretten) eingeführt. Im Jahr 2016 gab die US-amerikanische Food and Drug Administration (FDA) eine Vorschrift zur Regulierung von E-Zigaretten heraus, mit der eine Meldung schädlicher und potenziell schädlicher Inhaltsstoffe (HPHC) verlangt wird. In Großbritannien legte die British Standards Institution (BSI) die Metalle fest, die bei E-Zigaretten zu überwachen sind. In der vorliegenden Studie wurde ein Verfahren für die gleichzeitige Bestimmung von 13 Metallen (Be, $\mathrm{Al}, \mathrm{Cr}$, $\mathrm{Fe}, \mathrm{Co}, \mathrm{Ni}, \mathrm{Cu}, \mathrm{As}, \mathrm{Se}, \mathrm{Ag}, \mathrm{Cd}, \mathrm{Sn}$ und $\mathrm{Pb}$ ) im E-Zigaretten-Aerosol entwickelt und validiert. Außerdem wurden Matrixeffekte von Hauptbestandteilen im Aerosol mittels Glycerin- oder 1,2-Propylenglykol-Lösung untersucht. Das E-Zigaretten-Aerosol wurde durch eine rotierende Rauchmaschine nach der von der CORESTA empfohlenen Methode Nr. 81 erzeugt und mit einem elektrostatischen Abscheider, der an eine Waschflasche (Impinger) mit Salpetersäure gekoppelt ist, aufgefangen. Das aufgefangene Aerosol wurde in Salpetersäure aufgelöst und ein Teil dieser Lösung wurde mittels Massenspektrometrie mit induktiv gekoppeltem Plasma (ICP-MS) mit einer 
Kollisions-/Reaktionszelle analysiert.

Die Linearität der Kalibrierkurve wurde für jeden Analyten in dem Bereich von 0,2 bis $100 \mathrm{ng} / \mathrm{ml}$ beobachtet; die Korrelationskoeffizienten betrugen mindestens 0,998, die mittlere Wiederfindungsrate jeder Standardkonzentration lag zwischen 92,6 und 104,5\% und die relative Standardabweichung betrug max. 9,5\%. Die Genauigkeit, Wiederholbarkeit und Spezifität wurden validiert, indem das E-Zigaretten-Aerosol mit drei verschiedenen Mengen von Analyten angereichert wurde; die mittlere Wiederfindungsrate jeder Anreicherungskonzentration lag zwischen 88,7 und $110,3 \%$ und die relative Standardabweichung betrug max. 9,2\% für alle Analyte. Für einige Analyte, insbesondere für $\mathrm{Al}, \mathrm{Fe}, \mathrm{Cu}$ und $\mathrm{Sn}$, lag eine Hintergrundkontamination aus dem Aerosolerzeugungs- und Auffangsystem vor. Die potenziellen Kontaminationsquellen sollten identifiziert und kontrolliert werden, um die Auswirkungen der Kontamination auf die Quantifizierung zu reduzieren. Darüber hinaus sollten die tatsächlichen Werte für Proben zusammen mit einer Methodenblindwertstatistik berichtet werden. Eine Zunahme der Konzentrationen von Glycerin und 1,2-Propylenglykol in der präparierten Probe führte zur Überschätzung von As und Se. Zur korrekten Quantifizierung von As und Se sollte die Menge von Polyolen im aufgefangenen Aerosol überwacht und kontrolliert werden. [Beitr. Tabakforsch. Int. 28 (2018) 2-13]

\section{RESUME}

Les normes de sécurité et de qualité applicables aux cigarettes électroniques (e-cigarettes) ont été introduites au niveau régional. En 2016, la Food and Drug Administration (FDA) américaine a émis une règle relative aux e-cigarettes, qui exige la communication des composants nocifs et potentiellement nocifs (HPHC en anglais). $\mathrm{Au}$ Royaume-Uni, la British Standards Institution (BSI) a précisé les métaux devant être contrôlés sur les e-cigarettes. Dans le cadre de la présente étude, une méthode de détermination simultanée de 13 métaux (Be, $\mathrm{Al}, \mathrm{Cr}, \mathrm{Fe}, \mathrm{Co}$, $\mathrm{Ni}, \mathrm{Cu}, \mathrm{As}, \mathrm{Se}, \mathrm{Ag}, \mathrm{Cd}, \mathrm{Sn}$ et $\mathrm{Pb}$ ) présents dans l'aérosol des e-cigarettes fut mise au point et validée. Par ailleurs, l'effet de matrice des principaux composants de l'aérosol fut étudié à l'aide de solutions contenant du glycérol ou du 1,2-propylèneglycol.

L'aérosol de la cigarette électronique fut produit à l'aide d'une machine à fumer rotative, suivant la méthode $n^{\circ} 81$ recommandée par le CORESTA et fut prélevé par un précipitateur électrostatique couplé à un épurateur contenant de l'acide nitrique. L'aérosol prélevé fut dissout dans l'acide nitrique et une aliquote de cette solution fut analysée par un spectromètre de masse à couplage inductif(ICP-MS) équipé d'une cellule de collision/réaction.

La linéarité de la courbe de calibration fut observée dans une plage allant de 0,2 à $100 \mathrm{ng} / \mathrm{ml}$ pour chaque analyte; les coefficients de corrélation s'élevèrent à 0,998 voire plus, la récupération moyenne de chaque niveau normalisé oscilla entre 92,6 et $104,5 \%$ et l'écart-type relatif ne dépassa pas $9,5 \%$. La précision, la répétabilité et la spécificité furent validées en ajoutant trois quantités différentes d'analytes à l'aérosol de l'e-cigarette; la récupération moyenne pour chaque niveau ajouté oscilla entre 88,7 et $110,3 \%$ tandis que l'écart-type relatif ne dépassa pas 9,2\% pour la totalité des analytes. Une contamination de base imputable au système de production et de prélèvement de l'aérosol fut observée pour certains analytes, notamment l'aluminium, le fer, le cuivre et l'étain. Les sources potentielles de contamination devraient être identifiées et maîtrisées afin de réduire l'incidence de la contamination sur la quantification. En outre, les valeurs réelles des échantillons devraient être accompagnées des statistiques de l'essai à blanc. L'augmentation des concentrations de glycérol et de 1,2-propylèneglycol dans l'échantillon préparé causa une surestimation de l'arsenic et du sélénium. La quantité de polyols dans l'aérosol prélevé devrait être contrôlée et maîtrisée pour une quantification précise de l'arsenic et du sélénium. [Beitr. Tabakforsch. Int. 28 (2018) 2-13]

\section{INTRODUCTION}

Electronic cigarettes (e-cigarettes) have gained a global market share since their introduction into the European and American market in 2006 and 2007, respectively $(1,2)$. An e-cigarette is a battery-powered device to generate aerosol by heating a mixture, which typically contains humectants such as glycerol and/or 1,2-propylene glycol, water, nicotine and flavors (3-5). Basically, an e-cigarette consists of a battery, an atomizer and a cartridge, although the design is variable (6). A rechargeable e-cigarette has either a prefilled or refillable cartridge while a disposable one has a prefilled cartridge with a non-rechargeable battery. Device properties and performance vary among brands in pressure drop, the airflow rate required to generate aerosol, aerosol density and the total number of puffs per cartridge (7).

To date, concerns about the safety and quality of e-cigarettes have been raised. Since e-cigarettes contain metal components, which come in contact with the liquid, contamination of the aerosol with metals can occur. Several studies have shown the presence of metals in e-cigarette aerosol as well as variability in metal concentrations (8-12). WiLliams et al. found small particles composed of metals and silicates which were present in the aerosol of tested e-cigarettes (13).

Safety and quality standards for e-cigarettes have been introduced regionally. In 2016, the U.S. Food and Drug Administration (FDA) issued the Deeming Rule expanding the regulatory authority to cover all tobacco products, including e-cigarettes (14). The FDA requires e-cigarette manufacturers to report the quantities of harmful and potentially harmful constituents (HPHCs) in the liquid and aerosol, which was generated under a range of conditions of use, including both non-intense (e.g., lower levels of exposure) and intense (e.g., higher levels of exposure). In the United Kingdom, the British Standards Institution (BSI) published the standard for vaping products in 2015, which specified the metals to be monitored in the liquid and aerosol of e-cigarettes (15). A study for a simultaneous determination method for the metals specified in the HPHC list and the BSI standard has not been reported previously while determination methods for some of the metals were validated and reported $(8,11,16)$.

Inductively coupled plasma mass spectrometry (ICP-MS) has been accepted as an analytical technique for simul- 
taneous multi-element determinations at trace levels. However, the technique may suffer from spectral and nonspectral interferences $(17,18)$. Spectral interferences are caused by polyatomic, isobaric and doubly charged ions with the same nominal mass-to-charge ratio as the analyte of interest. Non-spectral interferences, referred to as matrix effects or matrix-induced signal variations, are highly dependent on sample matrices and instrumental conditions. Since matrix effects of e-cigarette aerosol in ICP-MS have rarely been studied, it is important to evaluate the impact on accuracy and precision.

The purpose of this study was to develop and validate a method for the simultaneous determination of 13 metals (Be, $\mathrm{Al}, \mathrm{Cr}, \mathrm{Fe}, \mathrm{Co}, \mathrm{Ni}, \mathrm{Cu}, \mathrm{As}, \mathrm{Se}, \mathrm{Ag}, \mathrm{Cd}, \mathrm{Sn}$ and $\mathrm{Pb}$ ) in e-cigarette aerosol. Furthermore, matrix effects in the presence of glycerol or 1,2-propylene glycol, which account for most of the aerosol, were investigated.

\section{MATERIALS AND METHODS}

\section{Reagents and electronic cigarettes}

Ultrapure nitric acid $\left(60-62 \% \mathrm{w} / \mathrm{w}, 1.38 \mathrm{~g} / \mathrm{cm}^{3}\right)$ and singleelement standards of $\mathrm{Be}, \mathrm{Sc}$ and $\mathrm{Y}$ in nitric acid $(1000 \mathrm{mg} / \mathrm{L})$ were purchased from Kanto Chemical (Tokyo, Japan). Multi-element standard XSTC-622B of Ag, Al, As, $\mathrm{B}, \mathrm{Ba}, \mathrm{Ca}, \mathrm{Cd}, \mathrm{Co}, \mathrm{Cr}, \mathrm{Cs}, \mathrm{Cu}, \mathrm{Fe}, \mathrm{Ga}, \mathrm{Ge}, \mathrm{K}, \mathrm{Li}, \mathrm{Mg}, \mathrm{Mn}$, Mo, Na, Ni, P, Pb, Rb, Sb, Se, Si, Sn, Sr, Ti, V, W, Zn and $\mathrm{Zr}$ in nitric acid $(10 \mathrm{mg} / \mathrm{L})$ was purchased from SPEX CertiPrep (Metuchen, NJ, USA). Tuning solution for ICPMS (Li, Y, Ce, Tl, and Co in nitric acid, $10 \mathrm{ng} / \mathrm{mL}$ ) was purchased from Agilent Technologies (Santa Clara, CA, USA). Glycerol (>99\% w/w) and 1,2-propylene glycol $(>99 \% w / w)$ were purchased from Wako Pure Chemical Industries (Osaka, Japan).

One commercially available e-cigarette was used for the validation study due to the lack of a reference e-cigarette. It had a rechargeable battery and a disposable cartomizer prefilled with a mixture of nicotine, water, glycerol, 1,2-propylene glycol and flavoring.

\section{Standard preparation}

The secondary internal standard solution $(100 \mu \mathrm{g} / \mathrm{mL})$ was prepared by transferring the primary standards of Sc and Y into a volumetric flask and filling up with $5 \% v / v$ nitric acid in ultrapure water (resistivity $>18.2 \mathrm{M} \Omega \cdot \mathrm{cm}$ ). Nine standards plus a blank $(0,0.2,0.5,1,2,5,10,20,50$ and $100 \mathrm{ng} / \mathrm{mL}$ ), containing $10 \mathrm{ng} / \mathrm{mL}$ of Sc and Y, were prepared by diluting commercially available standards in $5 \%$ $v / v$ nitric acid. The flasks were made of polypropylene or polyethylene and were cleaned before use by soaking and consecutive rinsing with acetone, concentrated nitric acid and ultrapure water. Disposable polypropylene pipette tips were rinsed with $5 \% \mathrm{v} / v$ nitric acid.

\section{Aerosol generation and collection}

Aerosol generation and collection were performed under ISO 3402 testing conditions (temperature $22 \pm 2{ }^{\circ} \mathrm{C}$, relative humidity $60 \pm 5 \%$ ) (19). An e-cigarette was smoked on a modified 20-port rotary smoking machine RM20H from Borgwaldt KC (Hamburg, Germany). It was connected to a pump system with a mass flow controller in order to generate aerosol while stopping the motion of a rotating metal ring on a metal plate, on which metal particles can be generated by attrition as the puff number greatly increases. Aerosol was generated according to CORESTA Recommended Method $\mathrm{N}^{\circ} 81$ (puff volume: $55 \pm 0.3 \mathrm{~mL}$, puff duration: $3 \pm 0.1 \mathrm{~s}$, puff interval: $30 \mathrm{~s}$, puff profile: rectangular shape) (20). Aerosol of 50 puffs was collected based on Health Canada Test Method T-109 (21). An electrostatic precipitator with a tungsten electrode tip (Borgwaldt KC, Hamburg, Germany) was used to trap aerosol in a glass tube. A glass impinger containing $30 \mathrm{~mL}$ of $5 \% v / v$ nitric acid, which was placed between an electrostatic precipitator and the pump system, was utilized to trap gaseous phase metals. All the batteries were fully charged before use. Method blanks were prepared in the same procedure as e-cigarette samples but with no e-cigarette in the sample holder.

\section{Sample preparation}

The collected aerosol was prepared and analyzed by modifying Standard Method 3125 developed by AMERICAN Public Health Association (22). The condensate trapped inside the glass tube was dissolved in $5 \% \mathrm{v} / \mathrm{v}$ nitric acid, and then $0.1 \mathrm{~mL}$ of internal standard stock solution was added. This solution was diluted and made up to $100 \mathrm{~mL}$ with nitric acid prior to instrumental analysis. The impinger solution was prepared and analyzed in the same way as the collected aerosol.

\section{ICP-MS analysis}

The metals were analyzed by an Agilent 7500cx ICP-MS equipped with a collision/reaction cell (Santa Clara, CA, USA). The operating conditions were optimized as shown in Table 1. To minimize oxide and double charged ratio, the

Table 1. Operating conditions for the ICP-MS.

\begin{tabular}{|c|c|c|}
\hline Parameter & \multicolumn{2}{|l|}{ Setting } \\
\hline RF power & \multicolumn{2}{|l|}{$1500 \mathrm{~W}$} \\
\hline Plasma gas flow rate & \multicolumn{2}{|c|}{$15 \mathrm{~L} / \mathrm{min}$} \\
\hline Auxiliary gas flow rate & \multicolumn{2}{|c|}{$\operatorname{Ar} 0.58 \mathrm{~L} / \mathrm{min}$} \\
\hline Carrier gas flow rate & \multicolumn{2}{|c|}{$\operatorname{Ar} 0.25 \mathrm{~L} / \mathrm{min}$} \\
\hline Peristaltic pump speed & \multicolumn{2}{|l|}{$0.1 \mathrm{rpm}$} \\
\hline Peristaltic pump tubing & \multicolumn{2}{|c|}{$1.02 \mathrm{~mm}$ inner diameter } \\
\hline Sampling cone & \multicolumn{2}{|c|}{ Pt sampling cone, $10 \mathrm{~mm}$ insert } \\
\hline Skimmer cone & \multicolumn{2}{|c|}{ Pt skimmer cone with $\mathrm{Cu}$ base } \\
\hline Sampling depth & \multicolumn{2}{|l|}{$12 \mathrm{~mm}$} \\
\hline Cell gas flow rate & \multicolumn{2}{|c|}{$\begin{aligned} \text { He } 5 \mathrm{~mL} / \mathrm{min}: & { }^{27} \mathrm{Al},{ }^{52} \mathrm{Cr},{ }^{59} \mathrm{Co},{ }^{60} \mathrm{Ni}, \\
& { }^{63} \mathrm{Cu},{ }^{75} \mathrm{As},{ }^{111} \mathrm{Cd},{ }^{208} \mathrm{~Pb},\end{aligned}$} \\
\hline Dwell time per isotope & $\begin{array}{l}0.33 \mathrm{~s}: \\
2 \mathrm{~s}:\end{array}$ & $\begin{array}{l}{ }^{9} \mathrm{Be},{ }^{27} \mathrm{Al},{ }^{52} \mathrm{Cr},{ }^{56} \mathrm{Fe},{ }^{59} \mathrm{Co}, \\
{ }^{60} \mathrm{Ni},{ }^{63} \mathrm{Cu},{ }^{107} \mathrm{Ag},{ }^{111} \mathrm{Cd},{ }^{118} \mathrm{Sn}, \\
{ }^{208} \mathrm{~Pb},{ }^{45} \mathrm{Sc},{ }^{89} \mathrm{Y} \\
{ }^{75} \mathrm{As},{ }^{78} \mathrm{Se}\end{array}$ \\
\hline Data point & 3 points & per peak \\
\hline Repetition & 3 times & \\
\hline
\end{tabular}


following parameters were tuned in standard (no gas) mode with $1 \mathrm{ng} / \mathrm{mL}$ tuning solution: radio frequency (RF) power, carrier and auxiliary gas flow rate, sampling depth and sample uptake rate. For each analyte, appropriate isotope, internal standard (Sc or Y) and cell gas (no gas, He or H2) mode were selected by comparing the measured counts between $5 \mathrm{ng} / \mathrm{mL}$ multi-element standard and blank. P/A factors were tuned before analysis to have a linear response over a wide range of analyte concentrations.

\section{Regression analysis}

The concentration of the analyte was determined using weighted least squares linear regression (23): $y=a x+b$, where $y$ is the ratio of the analyte response to the internal standard response, $a$ is the slope of the line, $x$ is the concentration of analyte, $b$ is the y-intercept of the line. The weighting factor was chosen based on the plot of analyte concentration versus standard deviation of analyte-tointernal standard response ratios.

\section{Method validation}

The developed method was validated based on the INTERNATIONAL CONFERENCE ON HARMONIZATION (ICH) guideline Q2(R1) and the EURACHEM/CITAC guide (24, 25). The evaluated validation parameters were specificity, linearity, range, accuracy, precision (repeatability) and limits of detection and quantification.
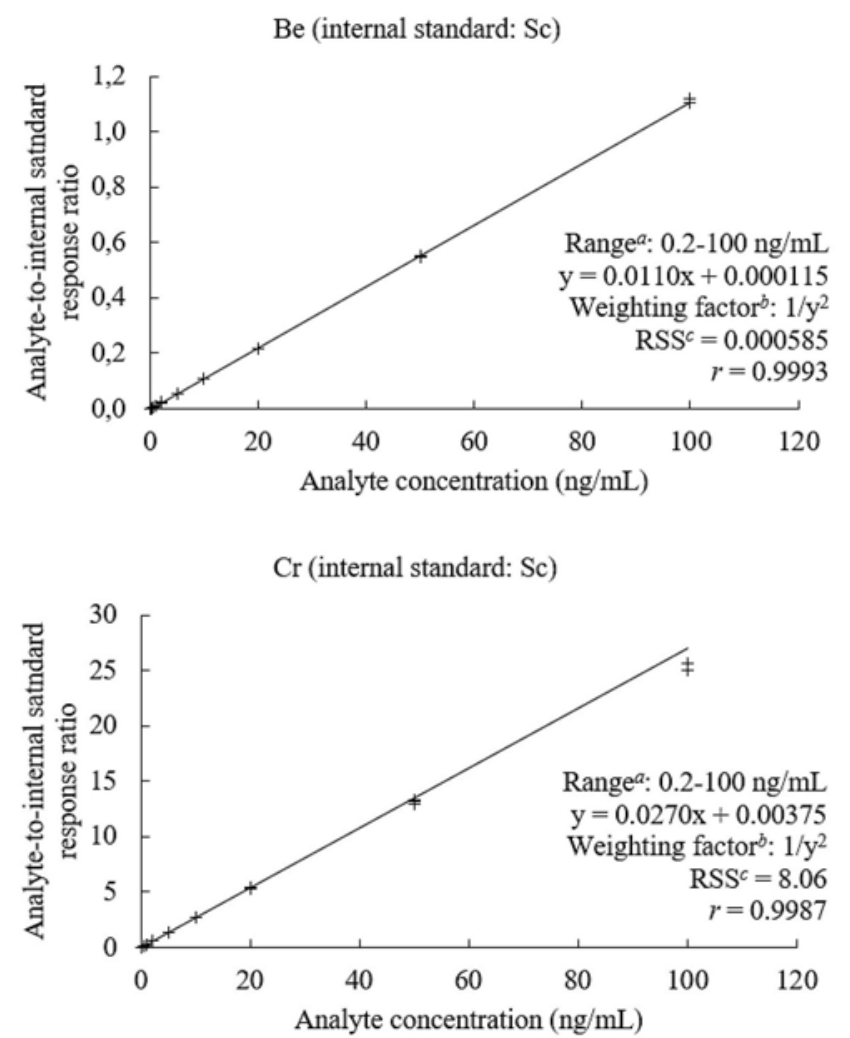

RESULTS

\section{Linearity and range}

Linearity was evaluated by analyzing standards with nine different concentrations $(0.2,0.5,1,2,5,10,20,50$ and $100 \mathrm{ng} / \mathrm{mL}$ ) in triplicate. Figure 1 shows regression parameters such as the correlation coefficient, slope and $y$-intercept of the calibration curve and residual sum of squares. Each correlation coefficient was 0.998 or larger. The mean recovery of each standard level for all analytes ranged from 92.6 to $104.5 \%$ with a relative standard deviation between 0.3 to $9.5 \%$ (Table 2 ).

\section{Limits of detection and quantification}

The limit of detection (LOD) and quantification (LOQ) were determined based on the standard deviation of ten independent measurements of the lowest standard level $(\mathrm{LOD}=3.3 \sigma / \mathrm{a}, \mathrm{LOQ}=10 \sigma / \mathrm{a})$. The results showed each LOQ was below the lowest concentration of standards (Table 3).

\section{Accuracy and precision}

Accuracy and repeatability were evaluated by spiking and recovery tests due to no reference e-cigarettes being available. The collected aerosol was split into two portions, and a defined amount of analytes was spiked into one
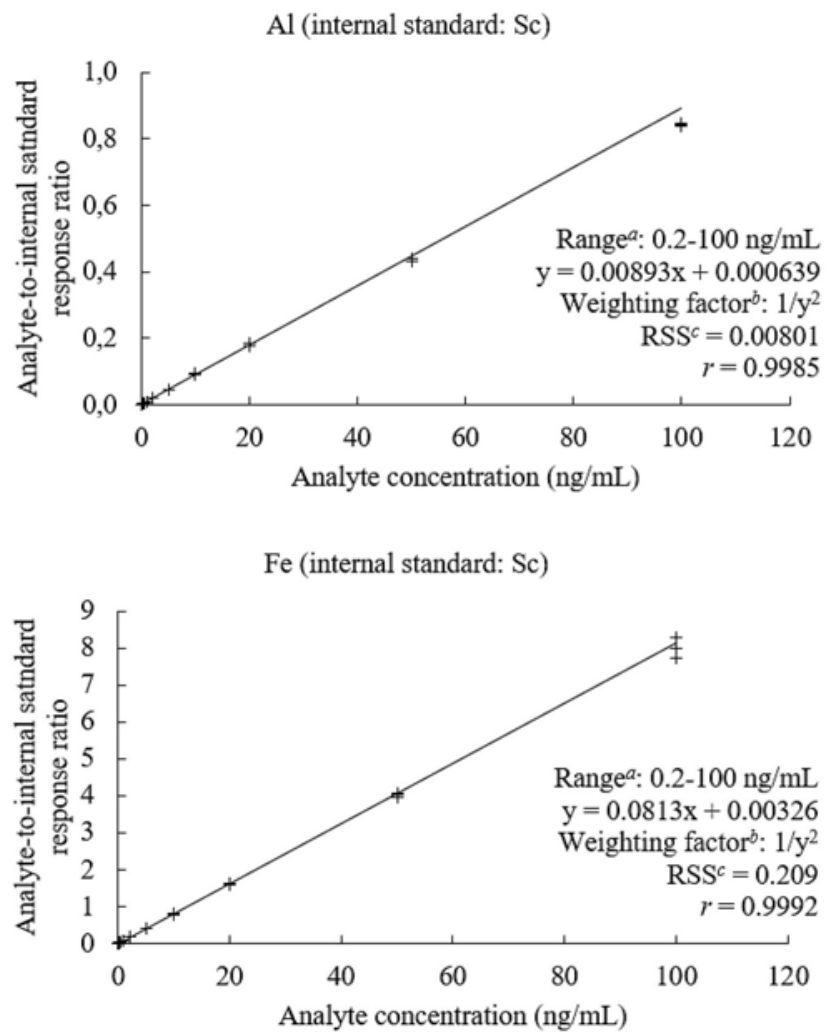

Figure 1. Calibration curve and regression parameters for each analyte. Nine levels of calibration standards $(0.2,0.5,1,2,5,10,20,50$ and $100 \mathrm{ng} / \mathrm{mL}$ for each analyte) were analyzed in three replicates. The most appropriate linear regression model of three (weighting factor: $1,1 / y$ and $1 / y^{2}$ ) was chosen based on the plot of analyte concentration $(x)$ versus standard deviation of analyte-to-internal standard response ratios (y). RSS: residual sum of squares. 


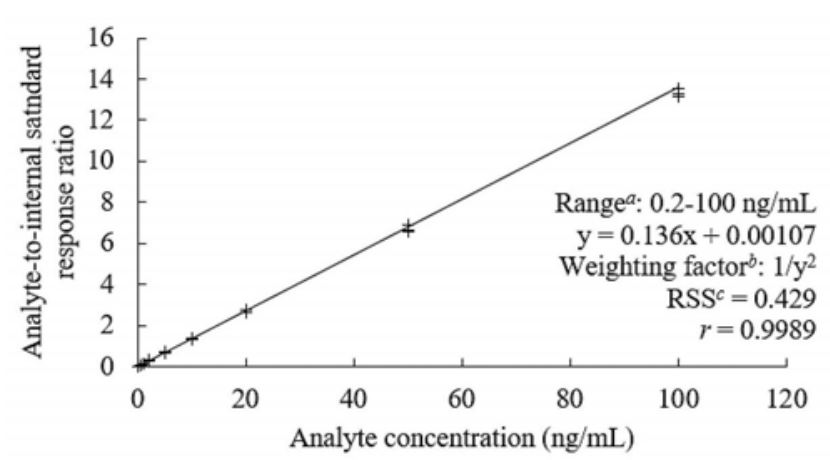

$\mathrm{Cu}$ (internal standard: $\mathrm{Y}$ )

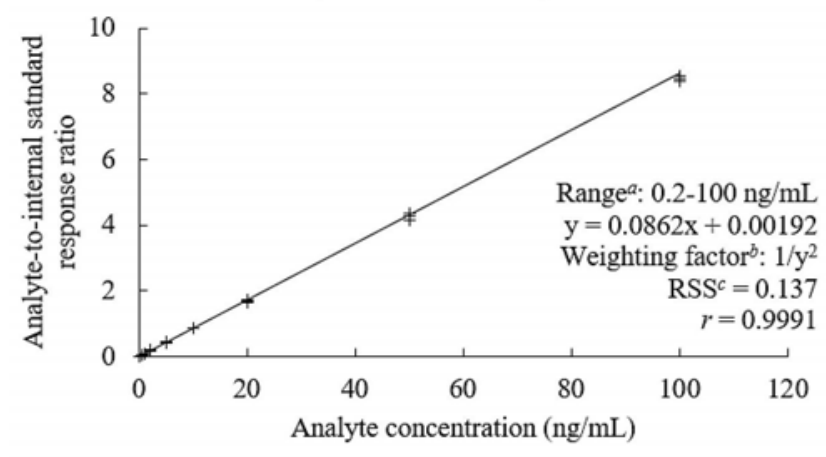

Se (internal standard: $\mathrm{Y}$ )

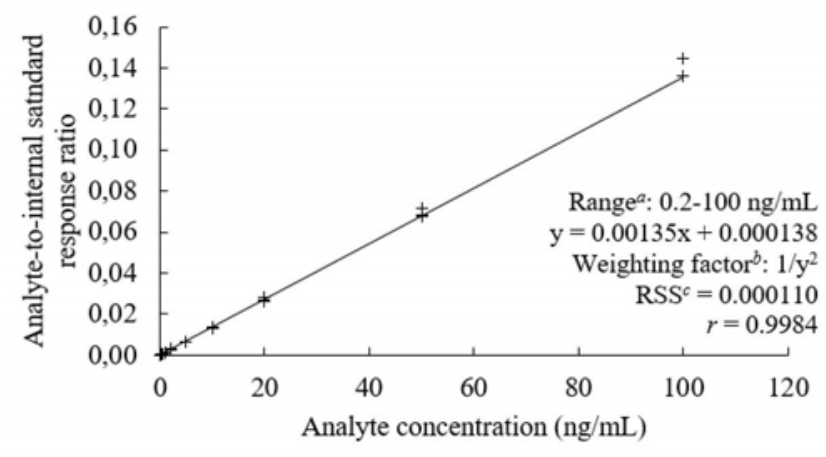

Cd (internal standard: $\mathrm{Y}$ )
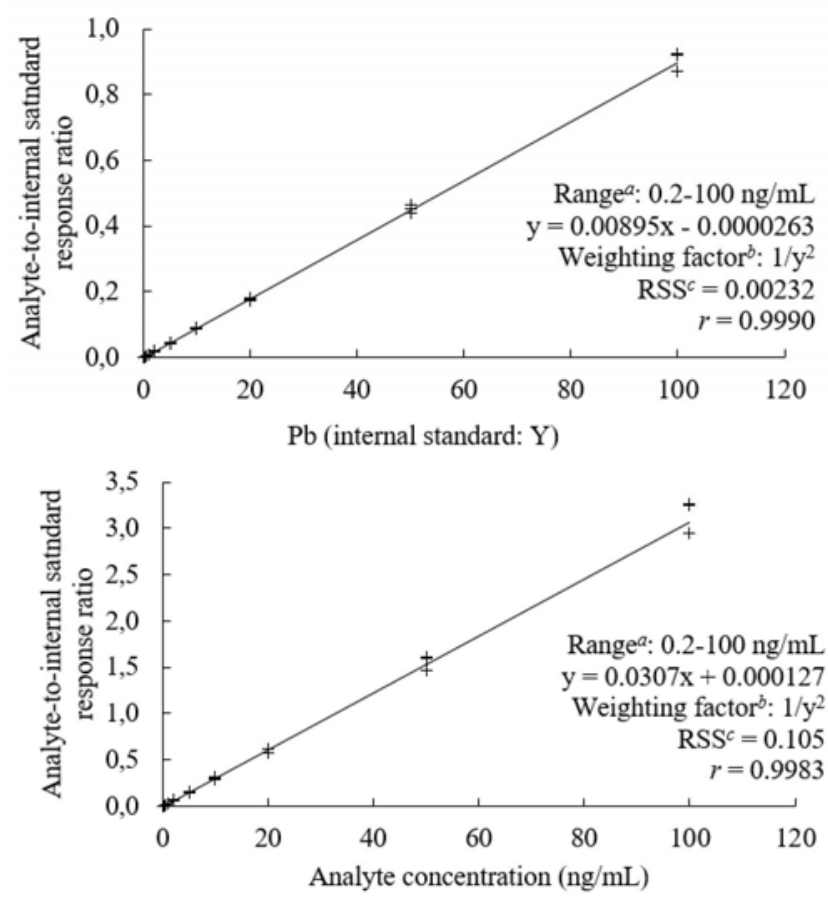

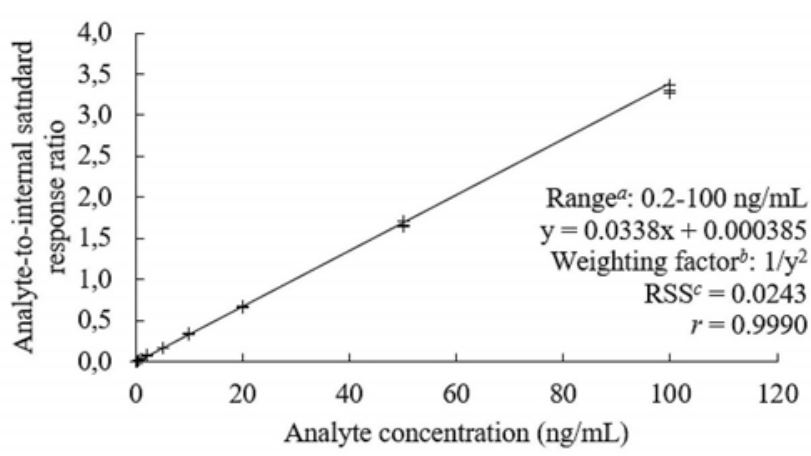

As (internal standard: $\mathrm{Y}$ )

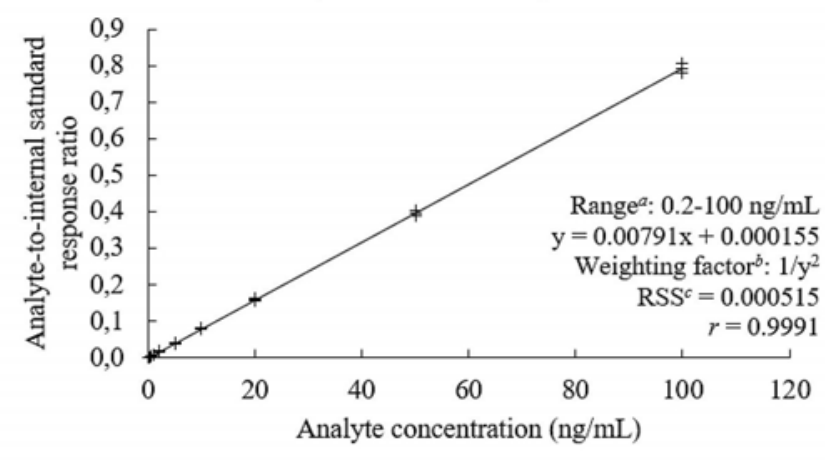

Ag (internal standard: Y)

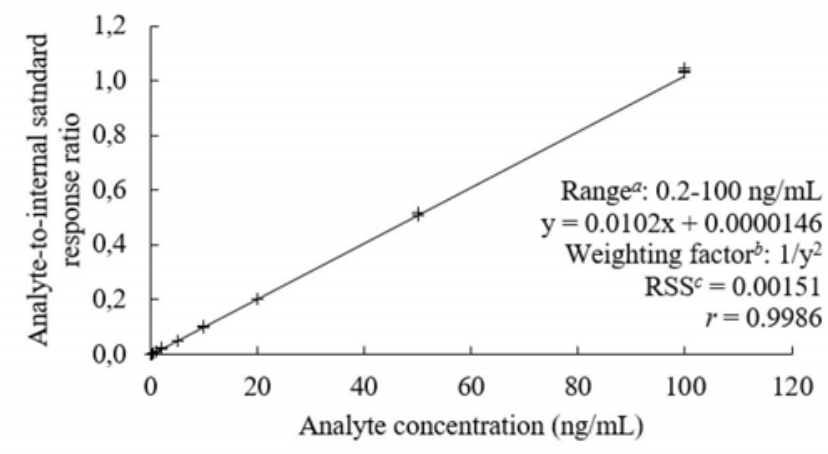

Sn (internal standard: $\mathrm{Y}$ )

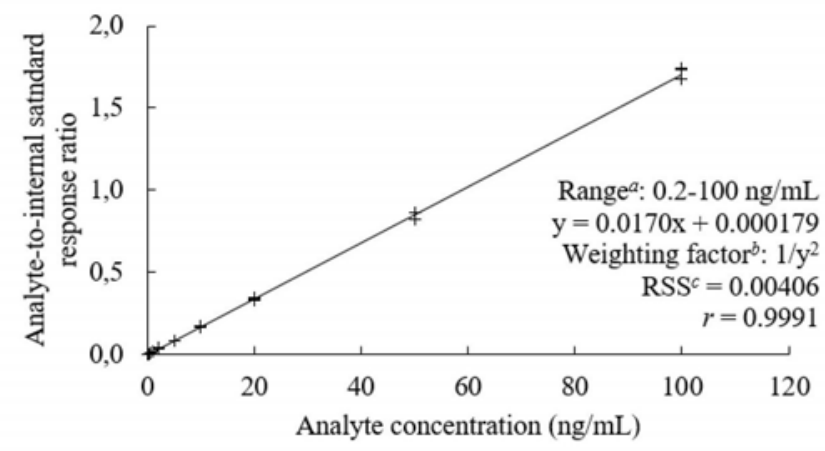

Figure 1 (contd.). Calibration curve and regression parameters for each analyte. Nine levels of calibration standards $(0.2,0.5,1$, $2,5,10,20,50$ and $100 \mathrm{ng} / \mathrm{mL}$ for each analyte) were analyzed in three replicates. The most appropriate linear regression model of three (weighting factor: $1,1 / y$ and $1 / y^{2}$ ) was chosen based on the plot of analyte concentration $(x)$ versus standard deviation of analyte-to-internal standard response ratios (y). RSS: residual sum of squares. 


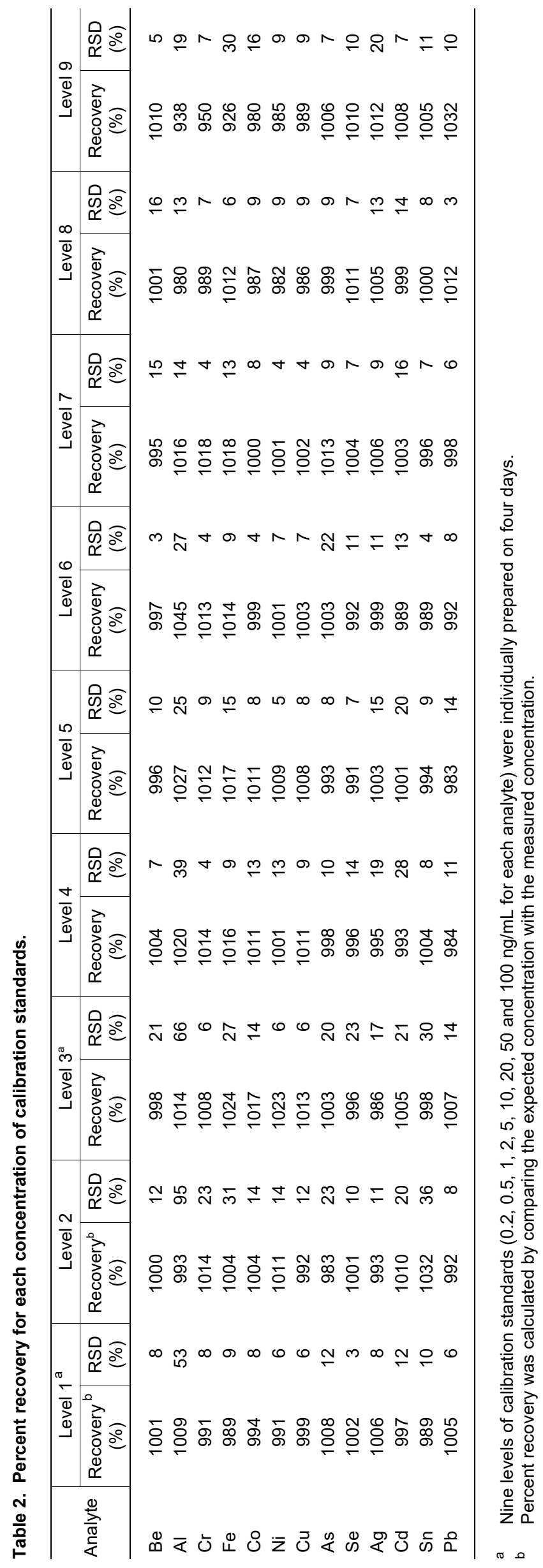


Table 3. Limits of detection (LOD) and quantification (LOQ) for each analyte.

\begin{tabular}{l|l|l}
\hline Analyte & $\begin{array}{c}\mathrm{LOD}^{\mathrm{a}} \\
(\mathrm{ng} / \mathrm{mL})\end{array}$ & $\begin{array}{l}\mathrm{LOQ}^{\mathrm{a}} \\
(\mathrm{ng} / \mathrm{mL})\end{array}$ \\
\hline $\mathrm{Be}$ & 91 & 277 \\
$\mathrm{Al}$ & 539 & 1630 \\
$\mathrm{Cr}$ & 165 & 500 \\
$\mathrm{Fe}$ & 146 & 443 \\
$\mathrm{Co}$ & 97 & 295 \\
$\mathrm{Ni}$ & 164 & 496 \\
$\mathrm{Cu}$ & 99 & 300 \\
$\mathrm{As}$ & 197 & 596 \\
$\mathrm{Se}$ & 544 & 1649 \\
$\mathrm{Ag}$ & 137 & 415 \\
$\mathrm{Cd}$ & 315 & 953 \\
$\mathrm{Sn}$ & 253 & 766 \\
$\mathrm{~Pb}$ & 245 & 743 \\
\hline
\end{tabular}

a LOD and LOQ were determined based on the slope and the standard deviation of the analyte-to-internal standard response ratios, which were obtained by 10 measurements of the lowest standard level $(0.2 \mathrm{ng} / \mathrm{mL})$ : $L O D=3.3 \mathrm{\sigma} / \mathrm{a}, \mathrm{LOQ}=10 \mathrm{\sigma} / \mathrm{a}$.

half. Three different amounts of analytes were added into aerosol collected by an electrostatic precipitator and impinger solution in triplicate, respectively $(0.1,0.5$ and 2 $\mu \mathrm{g}$ of each analyte per 50-puff aerosol). Percent recovery was calculated by comparing the spiked sample values with the unspiked sample values. For all analytes, the mean recoveries of three spiking levels ranged from 88.7 to $110.3 \%$ (Table 4). Each relative standard deviation was below $9.2 \%$ and slightly decreased for increasing spiking amounts.

\section{Blank test}

To measure background contamination during smoke runs and sample preparations, each method blank was individually prepared in the same procedure as e-cigarette samples. As shown in Table 5, Cr, Co, As, Se and Cd were not detected in any method blanks. $\mathrm{Be}, \mathrm{Ni}$ and $\mathrm{Pb}$ were detected in some method blanks but not quantified. The maximum concentrations of $\mathrm{Al}, \mathrm{Fe}, \mathrm{Cu}$ and $\mathrm{Sn}$ were above the lowest standard level.

\section{Matrix effects}

Matrix effects in the presence of glycerol or 1,2-propylene glycol were investigated by recovery and spike tests. Three levels of analytes were added into $0.1,0.2$ and $0.3 \% \mathrm{w} / \mathrm{v}$ of glycol or 1,2-propylene glycol solution in triplicate, respectively $(0.1,0.5$ and $2 \mu \mathrm{g}$ of each analyte per $100 \mathrm{~mL}$ of each solution). With the exception of As and Se, the mean recoveries of three spiking levels were between 85.5 to $108.8 \%$ and each relative standard deviation was within $6.9 \%$ (Tables 6,7 ). While the mean recoveries ranged from 98.3 to $106.1 \%$ for As and from 89.8 to $117.8 \%$ for Se at the lowest level of these polyol solutions, the mean recoveries were between 114.5 and $124.9 \%$ for As and between 126.1 and $144.8 \%$ for Se at the highest level.
Table 4. Results of spike and recovery test using electronic cigarette aerosol.

\begin{tabular}{|c|c|c|c|c|c|}
\hline \multirow{2}{*}{ Analyte } & \multirow{2}{*}{$\begin{array}{l}\text { Amount } \\
\text { spiked } \\
\text { (ng/mL) }\end{array}$} & \multicolumn{2}{|c|}{$\begin{array}{l}\text { Electrostatic } \\
\text { precipitator }^{a}\end{array}$} & \multicolumn{2}{|c|}{ Impinger solution } \\
\hline & & \begin{tabular}{|c|} 
Recovery \\
$(\%)^{b}$
\end{tabular} & $\begin{array}{c}\text { RSD } \\
(\%)\end{array}$ & $\begin{array}{c}\text { Recovery } \\
(\%)\end{array}$ & $\begin{array}{c}\text { RSD } \\
(\%)\end{array}$ \\
\hline \multirow[t]{3}{*}{$\mathrm{Be}$} & 1 & 973 & 10 & 989 & 9 \\
\hline & 5 & 942 & 9 & 973 & 5 \\
\hline & 20 & 943 & 6 & 979 & 4 \\
\hline \multirow[t]{3}{*}{$\mathrm{Al}$} & 1 & 990 & 62 & 1034 & 14 \\
\hline & 5 & 971 & 23 & 955 & 48 \\
\hline & 20 & 992 & 11 & 951 & 14 \\
\hline \multirow[t]{3}{*}{$\mathrm{Cr}$} & 1 & 1044 & 10 & 1072 & 5 \\
\hline & 5 & 1018 & 8 & 1063 & 8 \\
\hline & 20 & 1024 & 10 & 1056 & 3 \\
\hline \multirow[t]{3}{*}{$\mathrm{Fe}$} & 1 & 994 & 6 & 1056 & 8 \\
\hline & 5 & 998 & 2 & 1039 & 5 \\
\hline & 20 & 995 & 3 & 1047 & 4 \\
\hline \multirow[t]{3}{*}{ Co } & 1 & 1008 & 4 & 993 & 2 \\
\hline & 5 & 998 & 8 & 978 & 7 \\
\hline & 20 & 1008 & 7 & 983 & 3 \\
\hline \multirow[t]{3}{*}{$\mathrm{Ni}$} & 1 & 1004 & 23 & 1007 & 5 \\
\hline & 5 & 1000 & 5 & 978 & 9 \\
\hline & 20 & 1006 & 6 & 987 & 5 \\
\hline \multirow[t]{3}{*}{$\mathrm{Cu}$} & 1 & 986 & 32 & 1004 & 10 \\
\hline & 5 & 995 & 15 & 986 & 6 \\
\hline & 20 & 1006 & 3 & 996 & 7 \\
\hline \multirow[t]{3}{*}{ As } & 1 & 1000 & 15 & 975 & 14 \\
\hline & 5 & 1018 & 5 & 958 & 9 \\
\hline & 20 & 1034 & 2 & 983 & 6 \\
\hline \multirow[t]{3}{*}{$\mathrm{Se}$} & 1 & 954 & 92 & 924 & 17 \\
\hline & 5 & 1046 & 21 & 927 & 9 \\
\hline & 20 & 1086 & 9 & 946 & 3 \\
\hline \multirow[t]{3}{*}{$\mathrm{Ag}$} & 1 & 927 & 19 & 887 & 14 \\
\hline & 5 & 916 & 1 & 902 & 4 \\
\hline & 20 & 925 & 6 & 901 & 3 \\
\hline \multirow[t]{3}{*}{$\mathrm{Cd}$} & 1 & 1010 & 14 & 1046 & 28 \\
\hline & 5 & 993 & 7 & 1011 & 8 \\
\hline & 20 & 987 & 3 & 1012 & 5 \\
\hline \multirow[t]{3}{*}{ Sn } & 1 & 994 & 10 & 1011 & 7 \\
\hline & 5 & 973 & 2 & 1011 & 5 \\
\hline & 20 & 979 & 4 & 1009 & 7 \\
\hline \multirow[t]{3}{*}{$\mathrm{Pb}$} & 1 & 1036 & 7 & 1103 & 14 \\
\hline & 5 & 1025 & 2 & 1084 & 21 \\
\hline & 20 & 1024 & 5 & 1082 & 4 \\
\hline
\end{tabular}

a Aerosol of 50 puffs was collected by an electrostatic precipitator coupled to impinger containing nitric acid.

b Percent recovery was calculated by comparing the spiked sample value with the unspiked sample value $(n=3)$. 


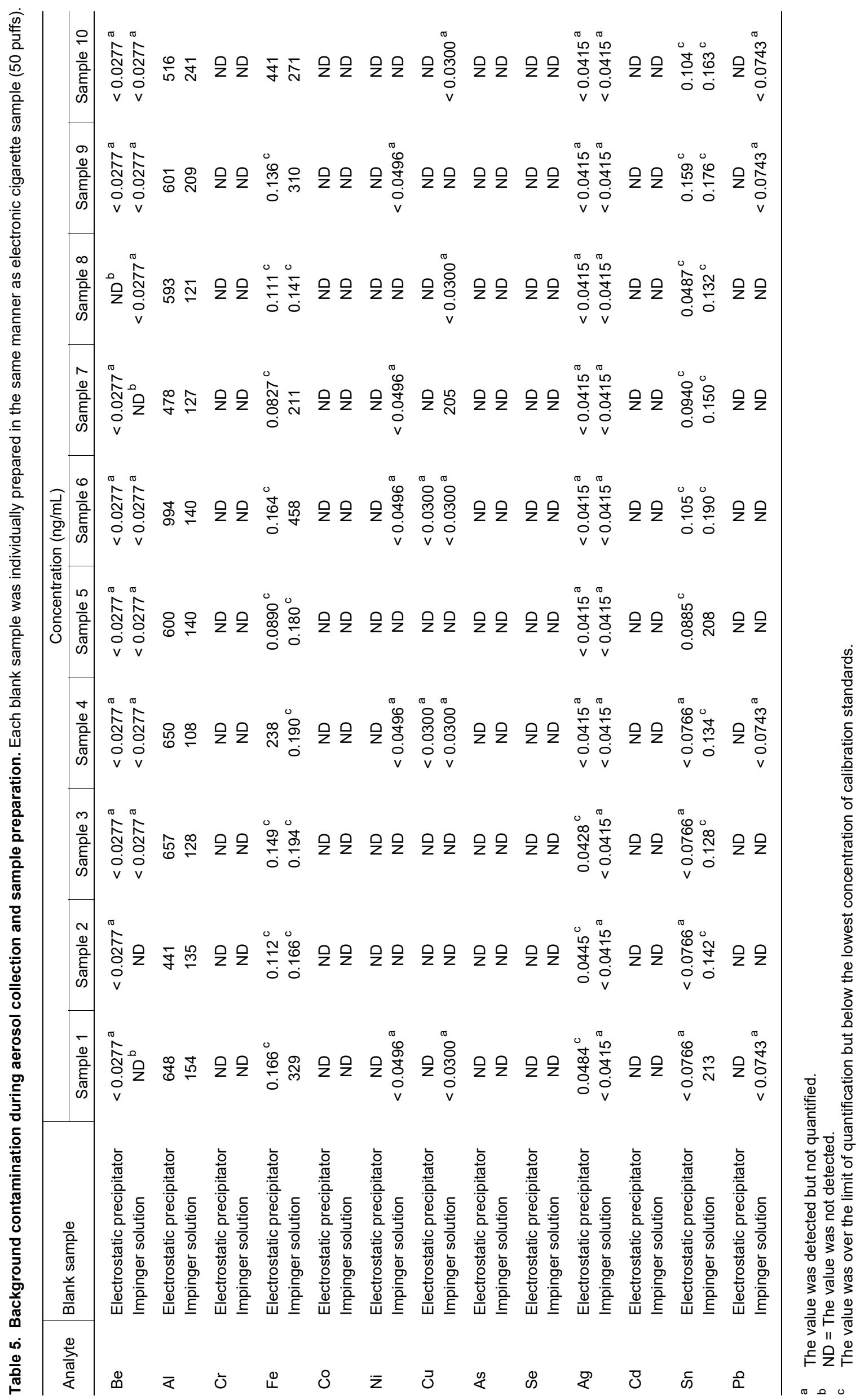


Table 6. Results of spike and recovery test using three levels of glycerol solution $(0.1,0.2$ and $0.3 \% w / v)$. Percent recovery was calculated by comparing the spiked sample value with the unspiked sample value $(n=3)$.

\begin{tabular}{|c|c|c|c|c|c|c|c|}
\hline \multirow{3}{*}{ Analyte } & \multirow{3}{*}{$\begin{array}{l}\text { Amount } \\
\text { spiked } \\
(\mathrm{ng} / \mathrm{mL})\end{array}$} & \multicolumn{6}{|c|}{ Glycerol solution } \\
\hline & & \multicolumn{2}{|c|}{$0.1 \%(w / v)$} & \multicolumn{2}{|c|}{$0.2 \%(w / v)$} & \multicolumn{2}{|c|}{$0.3 \%(w / v)$} \\
\hline & & Recovery (\%) & RSD (\%) & Recovery (\%) & RSD (\%) & Recovery (\%) & RSD (\%) \\
\hline \multirow[t]{3}{*}{$\mathrm{Be}$} & 1 & 958 & 10 & 924 & 13 & 1034 & 14 \\
\hline & 5 & 958 & 2 & 911 & 6 & 1022 & 5 \\
\hline & 20 & 962 & 5 & 916 & 3 & 1038 & 4 \\
\hline \multirow[t]{3}{*}{ Al } & 1 & 1088 & 10 & 1034 & 25 & 1067 & 1 \\
\hline & 5 & 1070 & 16 & 1035 & 13 & 1018 & 13 \\
\hline & 20 & 1037 & 5 & 1019 & 11 & 1006 & 21 \\
\hline \multirow[t]{3}{*}{$\mathrm{Cr}$} & 1 & 1003 & 6 & 1009 & 4 & 996 & 2 \\
\hline & 5 & 985 & 5 & 1001 & 9 & 982 & 6 \\
\hline & 20 & 968 & 9 & 974 & 3 & 974 & 1 \\
\hline \multirow[t]{3}{*}{$\mathrm{Fe}$} & 1 & 929 & 29 & 930 & 4 & 930 & 10 \\
\hline & 5 & 932 & 10 & 923 & 3 & 921 & 9 \\
\hline & 20 & 929 & 3 & 913 & 5 & 922 & 3 \\
\hline \multirow[t]{3}{*}{ Co } & 1 & 1005 & 15 & 1042 & 9 & 1068 & 12 \\
\hline & 5 & 991 & 5 & 1039 & 3 & 1052 & 1 \\
\hline & 20 & 985 & 4 & 1016 & 8 & 1050 & 3 \\
\hline \multirow[t]{3}{*}{$\mathrm{Ni}$} & 1 & 1010 & 11 & 1036 & 6 & 1077 & 8 \\
\hline & 5 & 994 & 5 & 1038 & 6 & 1060 & 6 \\
\hline & 20 & 982 & 2 & 1017 & 10 & 1052 & 3 \\
\hline \multirow[t]{3}{*}{$\mathrm{Cu}$} & 1 & 998 & 14 & 1035 & 2 & 1076 & 13 \\
\hline & 5 & 991 & 6 & 1040 & 2 & 1052 & 3 \\
\hline & 20 & 979 & 7 & 1021 & 11 & 1046 & 1 \\
\hline \multirow[t]{3}{*}{ As } & 1 & 983 & 16 & 991 & 53 & 1145 & 19 \\
\hline & 5 & 1024 & 3 & 1092 & 3 & 1165 & 21 \\
\hline & 20 & 1030 & 6 & 1102 & 15 & 1189 & 5 \\
\hline \multirow[t]{3}{*}{$\mathrm{Se}$} & 1 & 898 & 169 & 1039 & 110 & 1261 & 41 \\
\hline & 5 & 1078 & 33 & 1181 & 25 & 1305 & 11 \\
\hline & 20 & 1108 & 5 & 1214 & 11 & 1320 & 8 \\
\hline \multirow[t]{3}{*}{$\mathrm{Ag}$} & 1 & 975 & 12 & 898 & 12 & 922 & 12 \\
\hline & 5 & 1016 & 4 & 922 & 11 & 899 & 2 \\
\hline & 20 & 1030 & 5 & 925 & 12 & 902 & 4 \\
\hline \multirow[t]{3}{*}{$\mathrm{Cd}$} & 1 & 968 & 10 & 982 & 17 & 963 & 48 \\
\hline & 5 & 986 & 6 & 985 & 4 & 958 & 13 \\
\hline & 20 & 980 & 7 & 981 & 10 & 961 & 10 \\
\hline \multirow[t]{3}{*}{ Sn } & 1 & 947 & 21 & 988 & 4 & 969 & 10 \\
\hline & 5 & 958 & 7 & 959 & 8 & 944 & 7 \\
\hline & 20 & 970 & 7 & 954 & 11 & 947 & 1 \\
\hline \multirow[t]{3}{*}{$\mathrm{Pb}$} & 1 & 996 & 21 & 978 & 6 & 983 & 6 \\
\hline & 5 & 984 & 5 & 974 & 5 & 960 & 11 \\
\hline & 20 & 979 & 10 & 983 & 17 & 983 & 6 \\
\hline
\end{tabular}

\section{DISCUSSION}

The primary purpose of this study was to develop and validate a method for the simultaneous determination of 13 metals in e-cigarette aerosol, which were specified in the HPHC list and the BSI standard. The developed method was validated using one commercially available e-cigarette since analyte-certified reference e-cigarettes or typical analyte-free matrices were not available. Validation parameters were evaluated based on the ICH guideline and the
EURACHEM/CITAC guide $(24,25)$. Furthermore, matrix effects of major constituents in the aerosol were investigated using glycerol or 1,2-propylene glycol solutions. Initially, linearity was evaluated by analyzing multielement standards with 0.2 to $100 \mathrm{ng} / \mathrm{mL}$ of each analyte. Since the previous studies demonstrated the levels of some metals in e-cigarette aerosol varied among and within brands as well as product performance $(7,9,10)$, a wide range of analyte concentrations was applied. For all analytes, the correlation coefficient of the calibration curve 
Table 7. Results of spike and recovery test using three levels of 1,2-propylene glycol solution $(0.1,0.2$ and $0.3 \%$ w/v). Percent recovery was calculated by comparing the spiked sample value with the unspiked sample value $(n=3)$.

\begin{tabular}{|c|c|c|c|c|c|c|c|}
\hline \multirow{3}{*}{ Analyte } & \multirow{3}{*}{$\begin{array}{l}\text { Amount } \\
\text { spiked } \\
(\mathrm{ng} / \mathrm{mL})\end{array}$} & \multicolumn{6}{|c|}{ 1,2-Propylene glycol solution } \\
\hline & & \multicolumn{2}{|c|}{$0.1 \% w / v$} & \multicolumn{2}{|c|}{$0.2 \% w / v$} & \multicolumn{2}{|c|}{$0.3 \% w / v$} \\
\hline & & Recovery (\%) & RSD (\%) & Recovery (\%) & RSD (\%) & Recovery (\%) & RSD (\%) \\
\hline \multirow[t]{3}{*}{$\mathrm{Be}$} & 1 & 1000 & 4 & 963 & 15 & 1049 & 4 \\
\hline & 5 & 995 & 6 & 945 & 3 & 1047 & 2 \\
\hline & 20 & 997 & 4 & 958 & 14 & 1049 & 9 \\
\hline \multirow[t]{3}{*}{ Al } & 1 & 1050 & 21 & 1063 & 11 & 1008 & 69 \\
\hline & 5 & 1065 & 7 & 1021 & 10 & 998 & 13 \\
\hline & 20 & 1044 & 15 & 1018 & 1 & 982 & 3 \\
\hline \multirow[t]{3}{*}{$\mathrm{Cr}$} & 1 & 995 & 5 & 1009 & 2 & 1028 & 10 \\
\hline & 5 & 979 & 3 & 991 & 3 & 997 & 2 \\
\hline & 20 & 965 & 9 & 988 & 4 & 992 & 10 \\
\hline \multirow[t]{3}{*}{$\mathrm{Fe}$} & 1 & 968 & 15 & 948 & 2 & 973 & 11 \\
\hline & 5 & 938 & 0 & 930 & 6 & 945 & 5 \\
\hline & 20 & 948 & 4 & 930 & 4 & 946 & 2 \\
\hline \multirow[t]{3}{*}{ Co } & 1 & 999 & 9 & 1046 & 10 & 1079 & 7 \\
\hline & 5 & 985 & 8 & 1024 & 4 & 1063 & 9 \\
\hline & 20 & 986 & 6 & 1026 & 6 & 1053 & 9 \\
\hline \multirow[t]{3}{*}{$\mathrm{Ni}$} & 1 & 999 & 10 & 1043 & 9 & 1058 & 4 \\
\hline & 5 & 984 & 8 & 1021 & 2 & 1061 & 5 \\
\hline & 20 & 988 & 4 & 1031 & 1 & 1057 & 12 \\
\hline \multirow[t]{3}{*}{$\mathrm{Cu}$} & 1 & 1000 & 19 & 1035 & 4 & 1073 & 9 \\
\hline & 5 & 982 & 6 & 1032 & 15 & 1064 & 9 \\
\hline & 20 & 982 & 5 & 1026 & 2 & 1058 & 12 \\
\hline \multirow[t]{3}{*}{ As } & 1 & 1061 & 5 & 1142 & 15 & 1247 & 3 \\
\hline & 5 & 1046 & 5 & 1125 & 14 & 1249 & 9 \\
\hline & 20 & 1050 & 7 & 1132 & 1 & 1242 & 16 \\
\hline \multirow[t]{3}{*}{ Se } & 1 & 1178 & 20 & 1274 & 33 & 1432 & 20 \\
\hline & 5 & 1157 & 1 & 1283 & 4 & 1448 & 14 \\
\hline & 20 & 1156 & 6 & 1289 & 11 & 1444 & 6 \\
\hline \multirow[t]{3}{*}{$\mathrm{Ag}$} & 1 & 1019 & 7 & 899 & 16 & 868 & 12 \\
\hline & 5 & 1001 & 6 & 908 & 1 & 855 & 9 \\
\hline & 20 & 1012 & 14 & 923 & 8 & 858 & 3 \\
\hline \multirow[t]{3}{*}{$\mathrm{Cd}$} & 1 & 978 & 17 & 992 & 1 & 968 & 28 \\
\hline & 5 & 961 & 5 & 974 & 6 & 965 & 10 \\
\hline & 20 & 984 & 8 & 989 & 10 & 978 & 6 \\
\hline \multirow[t]{3}{*}{ Sn } & 1 & 986 & 19 & 976 & 13 & 968 & 10 \\
\hline & 5 & 960 & 3 & 953 & 4 & 950 & 7 \\
\hline & 20 & 967 & 8 & 959 & 5 & 960 & 4 \\
\hline \multirow[t]{3}{*}{$\mathrm{Pb}$} & 1 & 988 & 13 & 980 & 26 & 989 & 13 \\
\hline & 5 & 948 & 2 & 960 & 10 & 978 & 15 \\
\hline & 20 & 971 & 5 & 974 & 1 & 1004 & 22 \\
\hline
\end{tabular}

was 0.998 or larger, the mean recovery of each standard level ranged from 92.6 to $104.5 \%$ and the relative standard deviation was within $9.5 \%$ (Figure 1, Table 2). Thus, the linear relationship of analyte concentration versus analyteto-internal standard response ratio was verified in the range specified for each analyte.

For the e-cigarette employed for this validation study, the mass-percent composition of major constituents in the aerosol was determined by GC-FID (Gas Chromatography - Flame Ionization Detection). The aerosol consisted of
$2.0 \%$ of nicotine, $14.2 \%$ of water, $20.0 \%$ of glycerol, $63.4 \%$ of 1,2-propylene glycol and $0.5 \%$ of other constituents, which were presumed to be flavor constituents. TAYYARAH et al. reported nicotine, water, humectants involving glycerol and/or 1,2-propylene glycol and flavors in the aerosol of 5 different e-cigarettes ranged from 1-2\%, $10-19 \%, 70-85 \%$, and $3-11 \%$, respectively (4). By comparison, the tested e-cigarette was considered to be similar in chemical composition to these e-cigarettes.

Accuracy, repeatability and specificity were evaluated by 
spiking three different amounts of analytes into aerosol collected by electrostatic precipitator and impinger solution, respectively $(0.1,0.5$ and $2.0 \mu \mathrm{g}$ of each analyte per 50-puff aerosol). For all analytes, the mean recovery of each spiking level ranged from 88.7 to $110.3 \%$ with a relative standard deviation amounted to max. 9.2\% (Table 4). From the results, accuracy, repeatability and specificity were considered acceptable.

To measure background contamination during smoke run and sample preparation, method blanks were prepared and analyzed in 10 replicates. The results showed the amounts of $\mathrm{Al}, \mathrm{Fe}, \mathrm{Cu}$ and $\mathrm{Sn}$ varied and the maximum concentrations were above the lowest standard level, whereas the other analytes were undetectable or unquantifiable (Table 5). OTTE et al. reported background contamination was observed for linear and rotary smoking machines coupled with an electrostatic precipitator and/or impinger solution, showing background levels of contaminants varied among and within the tested aerosol generation and collection systems (26). In several studies, quartz fiber or mixed cellulose ester membrane filter pads were used as an alternative approach for aerosol collection $(10,11,27)$. However, the presence of metals in the filter method blank was observed. Therefore, the potential sources of contamination should be identified and controlled to reduce the impact of contamination on quantification. In addition, in order to quantitatively estimate the extent of background contamination, method blanks should be prepared and analyzed with every batch of samples.

Matrix effects in the presence of $0.1,0.2$ and $0.3 \% \mathrm{w} / \mathrm{v}$ glycerol or 1,2-propylene glycol, corresponding to the amounts of polyols in the tested e-cigarette aerosol per approximately 48, 97 and 145 puffs, were investigated. The results showed that the increase of the concentrations of polyols in the prepared sample led to the overestimation of $\mathrm{Se}$ and As while the mean recoveries of the tested e-cigarette aerosol per 50 puffs ranged from 92.4 to $108.6 \%$ (Tables 6, 7). By comparing the plot of analyte concentration versus response between solutions with and without polyols, the signal enhancement of As and Se in the presence of polyols was found (data not shown). LARSEN et al. reported the addition of carbon as methanol into aqueous solutions in combination with increased plasma power input enhanced the signal intensities of As and Se species in ICP-MS (28). Thus, the amount of polyols in the prepared sample should be monitored and controlled.

\section{ACKNOWLEDGEMENTS}

The author would like to thank M. Morokata for technical assistance with the experiments. He would also like to thank T. Kuroiwa and F. Milota for reviewing the manuscript. This work was supported by Japan Tobacco Incorporated.

\section{REFERENCES}

1. Noel, J.K., V.W. Rees, and G.N. Connolly: Electronic Cigarettes: A New 'Tobacco' Industry?; Tob. Control 20 (2011) 81. DOI: 10.1136/tc.2010.038562
2. Regan, A.K., G. Promoff, S.R. Dube, and R. Arrazola: Electronic Nicotine Delivery Systems: Adult Use and Awareness of the 'E-Cigarette' in the USA; Tob. Control 22 (2013) 19-23.

DOI: 10.1136/tobaccocontrol-2011-050044

3. Laugesen, M.: Safety Report on the Ruyan ${ }^{\circledR}$ E-Cigarette Cartridge and Inhaled Aerosol; Health New Zealand Ltd., Christchurch, New Zealand, October 30, 2008; available at: http://www.healthnz.co.nz/Ruyan CartridgeReport30-Oct-08.pdf(accessed January 2018).

4. Tayyarah, R. and G.A. Long: Comparison of Select Analytes in Aerosol from E-cigarettes with Smoke from Conventional Cigarettes and with Ambient Air; Regul. Toxicol. Pharmacol. 70 (2014) 704-710.

DOI: $10.1016 /$ j.yrtph.2014.10.010

5. Tierney, P., C.D. Karpinski, J.E. Brown, W. Luo, and J.F. Pankow: Flavour Chemicals in Electronic Cigarette Fluids; Tob. Control 25 (2016) e10-e15.

DOI: 10.1136/tobaccocontrol-2011-050044

6. Trtchounian, A. and P. Talbot: Electronic Nicotine Delivery Systems: Is There a Need for Regulation?; Tob. Control 20 (2011) 47-52.

DOI: $10.1136 /$ tc.2010.037259

7. Williams, M. and P. Talbot: Variability Among Electronic Cigarettes in the Pressure Drop, Airflow Rate, and Aerosol Production; Nicotine Tob. Res. 13 (2011) 1276-1283. DOI: 10.1093/ntr/ntr164

8. Goniewicz, M.L., J. Knysak, M. Gawron, L. Kosmider, A. Sobczak, J. Kurek, A. Prokopowicz, M. JablonskaCzapla, C. Rosik-Dulewska, C. Havel, P. Jacob III, and N. Benowitz: Levels of Selected Carcinogens and Toxicants in Vapour from Electronic Cigarettes; Tob. Control 23 (2014) 133-139.

DOI: 10.1136/tobaccocontrol-2012-050859

9. Williams, M., A. To, K. Bozhilov, and P. Talbot: Strategies to Reduce Tin and Other Metals in Electronic Cigarette Aerosol; PLoS One 10 (2015) e0138933. DOI: 10.1371/journal.pone.0138933

10. Mikheev, V.B., M.C. Brinkman, C.A. Granville, S.M. Gordon, and P.I. Clark: Real-Time Measurement of Electronic Cigarette Aerosol Size Distribution and Metals Content Analysis; Nicotine Tob. Res. 18 (2016) 1895-1902. DOI: 10.1093/ntr/ntw128

11. Palazzolo, D.L., A.P. Crow, J.M. Nelson, and R.A. Johnson: Trace Metals Derived from Electronic Cigarette (ECIG) Generated Aerosol: Potential Problem of ECIG Devices That Contain Nickel; Front. Physiol. 7 (2017) article 663. DOI: 10.3389/fphys.2016.00663

12. Williams, M., K. Bozhilov, S. Ghai, and P. Talbot: Elements Including Metals in the Atomizer and Aerosol of Disposable Electronic Cigarettes and Electronic Hookahs; PLoS ONE 12 (2017) e0175430. DOI: 10.1371 /journal.pone.0175430

13. Williams, M., A. Villarreal, K. Bozhilov, S. Lin, and P. Talbot: Metal and Silicate Particles Including Nanoparticles Are Present in Electronic Cigarette Cartomizer Fluid and Aerosol; PLoS ONE 8 (2013) e57987.

DOI: 10.1371/journal.pone.0057987

14. U.S. Food and Drug Administration (FDA): Tobacco Products - Products, Guidance \& Regulations Products, Ingredients \& Components - Vaporizers, E-Cigarettes, and other Electronic Nicotine Delivery 
Systems (ENDS); FDA, Silver Spring, MD, USA, last updated April 18, 2017; available at: https://www.fda. gov/TobaccoProducts/Labeling/Products Ingredients Components/ucm456610.htm (accessed January 2018).

15. British Standards Institution (BSI): PAS 54115:2015 Vaping Products, Including Electronic Cigarettes, E-Liquids, E-Shisha and Directly-Related Products. Manufacture, Importation, Testing and Labelling. Guide; BSI, London, United Kingdom, July 2015; available at: http://shop.bsigroup.com/ProductDetail? pid $=000000000030303130$ (accessed January 2018).

16. Otte, S., S. Nowak, and M. Intorp: Method Development and Validation for the Quantification of Metals in Liquids and Aerosol of E-Cigarettes; Presentation at the CORESTA SSPT Meeting, Jeju, Korea, October 5, 2015, Abstract ST10; available at: https://www.coresta. org/abstracts/method-development-and-validationquantification-metals-liquids-and-aerosol-e-cigarettes (accessed January 2018).

17. Thomas, R.: Practical Guide to ICP-MS; Marcel Dekker Incorporated, New York, NY, USA, 2004.

18. U.S. Environmental Protection Agency (EPA): Method 200.8: Determination of Trace Elements in Waters and Wastes by Inductively Coupled Plasma - Mass Spectrometry, Revision 5.4; EPA, Cincinnati, OH, USA, 1994, available at: https://www.epa.gov/homeland-securityresearch/epa-method-2008-determination-traceelements-waters-and-wastes (accessed January 2018)

19. International Organization for Standardization (ISO): International Standard ISO 3402:1999 - Tobacco and Tobacco Products - Atmosphere for Conditioning and Testing; ISO, Geneva, Switzerland, December 1999; available at: https://www.iso.org/standard/28324.html (accessed January 2018).

20. Cooperation Centre for Scientific Research Relative to Tobacco (CORESTA): CORESTA Recommended Method $\mathrm{N}^{\circ} 81$ - Routine Analytical Machine for E-Cigarette Aerosol Generation and Collection - Definitions and Standard Conditions; CORESTA, June 2015; available at: https://www.coresta.org/routineanalytical-machine-e-cigarette-aerosol-generation-andcollection-definitions-and-standard (accessed January 2018)

21. Health Canada: Official Method T-109-Determination of $\mathrm{Ni}, \mathrm{Pb}, \mathrm{Cd}, \mathrm{Cr}, \mathrm{As}$ and $\mathrm{Se}$ in Mainstream Tobacco Smoke; Health Canada, Ottawa, Canada, December 1999.

22. American Public Health Association (APHA), American Water Works Association (AWWA), and Water Environment Federation (WEF): Standard Methods for the Examination of Water and Wastewater, $20^{\text {th }}$ Edition - 3125 Metals by Inductively Coupled Plasma/Mass Spectrometry; APHA, Washington, DC, USA, 1999.
23. Almeida, A.M., M.M. Castel-Branco, and A.C. Falcão: Linear Regression for Calibration Lines Revisited: Weighting Schemes for Bioanalytical Methods; J. Chromatogr. B 774 (2002) 215-222. DOI: 10.1016/S1570-0232(02)00244-1

24. International Conference on Harmonisation of Technical Requirements for Registration of Pharmaceuticals for Human Use (ICH): Validation of Analytical Procedures: Text and Methodology Q2(R1); ICH, Geneva, Switzerland, 2005; available at: http://www.ich.org/ products/guidelines/quality/quality-single/article/vali dation-of-analytical-procedures-text-and-methodology. html (accessed January 2018).

25. Eurachem and Cooperation on International Traceability in Analytical Chemistry (CITAC); Quantifying Uncertainty in Analytical Measurement, 3rd Edition; Eurachem, Olomouc, Czech Republic, 2012; available at: https://www.eurachem.org/ndex.php/publications/ guides/quam (accessed January 2018).

26. Otte, S., S. Nowak, and M. Intorp: Impact of Different Vaping Machines on Metal Contaminations of E-cigarette Aerosols; Poster presented at the CORESTA Congress, Berlin, Germany, October 12, 2016, abstract STPOST04; available at: https://www.coresta.org/ abstracts/impact-different-vaping-machines-metalcontaminations-e-cigarette-aerosols-30242.html (accessed January 2018).

27. Schober, W., K. Szendrei, W. Matzen, H. OsianderFuchs, D. Heitmann, T. Schettgen, R.A. Jörres, and H. Fromme: Use of Electronic Cigarettes (E-Cigarettes) Impairs Indoor Air Quality and Increases FeNO Levels of E-cigarette Consumers; Int. J. Hyg. Environ. Health 217 (2014) 628-637. DOI: 10.1016/j.ijheh.2013.11.003

28. Larsen, E.H. and S. Stürup: Carbon-Enhanced Inductively Coupled Plasma Mass Spectrometric Detection of Arsenic and Selenium and its Application to Arsenic Speciation; J. Anal. At. Spectrom. 9 (1994) 1099-1105. DOI: 10.1039/JA9940901099

Corresponding author:

Shintaro Ohashi

Product Quality Research Center

Japan Tobacco Incorporated

6-2, Umegaoka, Aoba-ku

Yokohama, Kanagawa, Japan

E-mail: shintaro.a.ohashi@jt.com 